\title{
The efficiency of surface-applied corrosion inhibitors as a method for the repassivation of corroded reinforcement bars embedded in ladle furnace slag mortars
}

\author{
María Isabel Prieto, Alfonso Cobo, Ángel Rodríguez, María de las Nieves González
}

\section{H I G H L I G H T S}

- The corrosion process in reference specimens and LFS specimens is similar.

- In reference specimens with $0.8 \% \mathrm{Cl}$, the inhibitor reduces the corrosion rate.

- Reference specimens with 1.2 and $2 \% \mathrm{Cl}$, inhibitor does not reduce the corrosion rate.

- In LFS specimens and $\mathrm{Cl}$ of over $0.4 \%$, the bars remain in an active state.

- The surface inhibitors are not effective in states of advanced corrosion.

\section{A B S T R A C T}

Surface-applied corrosion inhibitors are investigated as an efficient method for the repassivation of cor-roded rebars embedded in mortar specimens, with ladle furnace slag. Prismatic specimens measuring $6 \times 8 \times 2 \mathrm{~cm}^{3}$, into which 3 steel rebars had been embedded, were analyzed through electrochemical and gravimetric tests. The results show that the corrosion inhibitors are more effective on the reference specimens than on the specimens with LFS and are capable of lowering corrosion rate in specimens with chloride ion percentages of $0.8 \%$, but are not effective on any of the specimens with chloride ion percent-ages of $1.2 \%$ and $2.0 \%$ by weight of cement.

\section{Introduction}

The durability of reinforced concrete is, among other factors, affected by the corrosion of its reinforcements. One factor that triggers rebar corrosion is the presence of chlorides in quantities above the critical threshold proposed by the Technical Committee 60 CSC, RILEM (International Union of Testing and Research Laboratories for Materials and Structures) [1] and widely applied in various standards. This threshold is defined as total chloride ion content in fresh concrete of $0.4 \%$ by weight of cement [2-5] and numerous investigations have studied the behavior of concrete in the context of exposure to the action of chlorides [6-10].
Given the importance of environmental protection and the conservation of natural resources [11,12], recycling strategies have to be established for the use of industrial waste as a raw material in other materials. At present, various studies are underway on the use of waste products in reinforced concrete, such as fly ash, additions of boron, white slag from oxygen furnaces and black slag from electric arc furnaces [13-19]. In this study, Ladle Furnace (white) Slag (LFS), a by-product of the steel manufacturing process, is used in partial substitution of aggregate and cement, with its consequent economic and environmental advantages [20-22].

The corrosion behavior of the rebars embedded in the LFS mortars, which were contaminated by chloride, has been investigated in our earlier works $[23,24]$, which confirmed that there are no significant differences between the reference specimens and the LFS mortars.

In these studies, it was confirmed that the percentages of chloride ions above $0.4 \%$ by weight of cement produced the depassivation of the steel, regardless of the type of mortar that was used. In 
addition, similar corrosion rate were observed between the reference specimens and the LFS specimens, for percentages of chloride ions of $0.8 \%, 1.2 \%$ and $2 \%$ by weight of cement.

Surface-applied corrosion inhibitors are at present one of various methods in use that aim to extend the useful life of reinforced concrete structures, in order to prevent or at least to delay corrosion in reinforced concrete structures. There are numerous investigations on both organic and inorganic inhibitors, due to the economic and environmental impact of corrosion on reinforced concrete, which study their influence on reinforced concrete and the conditions under which they may be effective [25-32]. There are also investigations on the efficiency of surface-applied corrosion inhibitors in mortars with fly-ash additives [33] and in the case of aminoalcohol-based inhibitors, a study has shown that the most efficient transport mechanism is diffusion in a dissolved state, so the greater absorption of the mortars with LFS slags could facilitate penetration of the inhibitor [34].

However, no investigations have reported on the efficiency of inhibitors that are applied to concrete that contains LFS, which is the aim of this present work.

The influence of the addition of LFS slags on the efficacy of surface corrosion inhibitors are studied in this work as a method for the repassivation of corroded reinforcements. In the case that the corrosion inhibitors behave in a similar way to the reference mortar specimens and the specimens with LFS slags, then that would imply a further positive point in favor of the recycling of slags employing them as a raw material in concrete, with the consequence economic and environmental advantages.

\section{Experimental work}

\subsection{Materials}

The materials used in this investigation for the preparation of the mortar specimens were Portland cement CEM I/42.5 R, as defined by RC-08 [35], urban mains water, and silica sand. The chemical compositions and physical characteristics of these materials are found in Table 1.

The LFS slags, a by-product of the Tubos Reunidos factory in Álava (Spain), were weathered for a period of two years at the Materials Laboratory of the Superior Polytechnic School of the University of Burgos. Characterization of the LFS classified it as a 0/1 sand according to European standard UNE-EN 13139 [36] and determined its physical and chemical properties that are detailed in Table 2 [22].

A surface-applied corrosion inhibitor is a combination of amino alcohols and organic and inorganic inhibitors that protect both the anodic and the cathodic part of the corrosion cell. It is designed to penetrate through the concrete pores by diffusion and to migrate to the steel rebars at a rate of 2 to $20 \mathrm{~mm} /$ day, depending on
Table 2

Physical characteristics and chemical composition of Ladle Furnace (white) Slag.

\begin{tabular}{|c|c|c|c|c|}
\hline & Chemical composition & & Physical characteristics & \\
\hline LFS & $\begin{array}{l}\mathrm{CaO} \\
\mathrm{SiO}_{2} \\
\mathrm{Al}_{2} \mathrm{O}_{3} \\
\mathrm{MgO} \\
\left(\mathrm{Fe}_{2} \mathrm{O}_{3}+\mathrm{MnO}+\mathrm{TiO}_{2}+\right. \\
\left.+\mathrm{SO}_{3}+\mathrm{Na}_{2} \mathrm{O}+\mathrm{K}_{2} \mathrm{O}\right)\end{array}$ & $\begin{array}{l}56 \% \\
17 \% \\
11 \% \\
10 \% \\
6 \%\end{array}$ & $\begin{array}{l}\text { Density } \\
\text { Specific surface area } \\
\text { Chlorides } \\
\text { Total sulfur, expressed as } \\
\text { Sulfate ions } \\
\text { Clayey clumps } \\
\text { Organic material }\end{array}$ & $\begin{array}{l}2.65 \mathrm{~g} / \mathrm{cm}^{3} \\
2064 \mathrm{~cm}^{2} / \mathrm{g} \\
\text { None } \\
<1 \% \\
\text { None } \\
\text { None }\end{array}$ \\
\hline
\end{tabular}

concrete compactness. The product, once it reaches the steel surface, forms a continuous protective layer that is resistant to water and to aggressive agents without modifying the physical properties of the concrete. The characteristics of the inhibitor are shown in Table 3.

\subsection{Dosage criteria}

Two series of mortars were fabricated to evaluate the efficiency of the corrosion inhibitors: one in which the aggregate and the cement were partially substituted by ladle furnace (white) slag (MAE) and another as a reference specimen (MAC). All the dosages were based on the following specifications, which have previously been evaluated in earlier studies [22]:

- A ratio of cement/sand/water by weight of $1: 6: w$, with the necessary quantity of water to achieve a slump of $175 \pm 10 \mathrm{~mm}$.

- A compressive mechanical strength at 28 days of at least $7.5 \mathrm{~N} / \mathrm{mm}^{2}$.

- $30 \%$ of cement and $25 \%$ of sand were substituted for ladle furnace white slag in the LFS specimens.

Moreover, different amounts of $\mathrm{CaCl}_{2}$ were introduced during mixing, in order to obtain chloride ion percentages of $0 \%, 0.4 \%, 0.8 \%, 1.2 \%$ and $2 \%$ by weight of cement in each series of specimens. A total of 10 different specimens were obtained, all of which in duplicate, the dosages for which are specified in Table 4.

The dosage of the surface-applied inhibitor in the amounts recommended by the manufacturer amounted to a total of $0.500 \mathrm{~kg} / \mathrm{m}^{2}$, after impregnation up until saturation of the substrate with 5 layers of inhibitor.

\subsection{Phases of the study}

First of all, $6 \times 8 \times 2 \mathrm{~cm}^{3}$ prismatic mortar specimens were prepared, into which 3 steel rebars with a diameter of $6 \mathrm{~mm}$ and a length of $15 \mathrm{~cm}$, were embedded in the mortar to a depth of $6 \mathrm{~cm}$. The interface was sealed with an adhesive tape, $5 \mathrm{~cm}$ in width, to protect the steel-concrete from any possible local attack by differential aeration (Fig. 1). The mould was filled in layers for the preparation of the specimens: the first up to the position of the rebars and the second up to the upper part of the mould. Both specimens were compacted through the application of 25 evenly spaced blows.

Table 1

Physical characteristics and chemical composition of cement, sand, and water.

\begin{tabular}{|c|c|c|c|c|}
\hline & Chemical composition & & Physical characteristics & \\
\hline Cement & $\begin{array}{l}\mathrm{SO}_{3} \\
\mathrm{Cl}^{-} \\
\text {Loss on ignition } \\
\text { Insoluble residue }\end{array}$ & $\begin{array}{l}3.20 \% \\
0.01 \% \\
3.20 \% \\
1.40 \%\end{array}$ & $\begin{array}{l}\text { Blaine specific surface area } \\
\text { Le Chatelier expansion } \\
\text { Time setting began } \\
\text { Time setting ended }\end{array}$ & $\begin{array}{l}3400 \mathrm{~cm}^{2} / \mathrm{g} \\
0 \mathrm{~mm} \\
170 \mathrm{~min} \\
220 \mathrm{~min}\end{array}$ \\
\hline Sand & $\begin{array}{l}\mathrm{S}, \mathrm{SO}_{3}, \mathrm{Cl}^{-} \text {and particles of low specific weight } \\
\text { Fine }\end{array}$ & $\begin{array}{l}0.00 \% \\
0.78 \%\end{array}$ & $\begin{array}{l}\text { Sand equivalent } \\
\text { Real density } \\
\text { Normal absorption coefficient } \\
\text { Saturated } \\
\text { Surface dry (SSD) density } \\
\text { Clayey clumps } \\
\text { Coefficient of } \\
\text { Course aggregate type } \\
\text { Soft particles }\end{array}$ & $\begin{array}{l}78 \\
2.619 \mathrm{~g} / \mathrm{cm}^{3} \\
15 \% \\
2.630 \mathrm{~g} / \mathrm{cm}^{3} \\
0.01 \% \\
\\
0.26 \% \\
0.93 \%\end{array}$ \\
\hline Water & $\begin{array}{l}\text { Ammonium } \\
\text { Steel } \\
\text { Manganese } \\
\text { Aluminium } \\
\text { Free chloride } \\
\text { Total chloride } \\
\text { Calcium }\end{array}$ & $\begin{array}{l}0.01 \% \\
0.06 \% \\
0.00 \% \\
0.06 \% \\
0.39 \% \\
0.45 \% \\
4.68 \%\end{array}$ & $\begin{array}{l}\mathrm{pH} \\
\text { Turbidity } \\
\text { Conductivity }\end{array}$ & $\begin{array}{l}8.86 \\
0.17 \mathrm{NTU} \\
47.70 \mathrm{mS} / \mathrm{m}\end{array}$ \\
\hline
\end{tabular}


Table 3

Physical characteristics of the corrosion inhibitor.

\begin{tabular}{cll}
\hline & \multicolumn{2}{l}{ Physical characteristics } \\
\hline Corrosion & Density & $1.13 \mathrm{~kg} / 1$ \\
inhibitor & Viscosity & $15 \mathrm{cps}$ to $23^{\circ} \mathrm{C}$ \\
& $\mathrm{pH}$ & $11( \pm 1)$ \\
& Physical state & Liquid \\
& Colout & Pale yellow \\
& Application & Min. $4^{\circ} \mathrm{C}$, Max $40^{\circ} \mathrm{C}$ (ambient and \\
& temperature & surface) \\
& Ignition point & None \\
\hline
\end{tabular}

The mould remained in a damp chamber for $24 \mathrm{~h}$, after which the specimens were removed from their moulds and were once again introduced into the damp chamber for setting and hardening over a period of 28 days. Once the specimens had been prepared, cured and naturally dried, they were gradually dampened, prior to tests on the corrosive behavior of their embedded rebars by means of electrochemical techniques (corrosion potential and corrosion rate). These tests were performed on both the LFS specimens and the reference specimens, over 290 and 270 days, respectively, in accordance with variations in the dampness of the specimens and the chloride ion percentages introduced at the time of mixing.

Having concluded the first phase, in which a representative number of measurements were taken in the aforementioned experimental process, a corrosion inhibitor was applied to the surface of both the LFS and the reference specimens.

The corrosion inhibitor was applied in accordance with the following process (Fig. 2):

The specimens were removed from the damp chamber for natural drying and the substrate was cleaned by mechanical means. A first coating of the inhibitor was applied up until saturation of the substrate with a brush.

Once the surface was dry, surface application of the inhibitor continued until $0.500 \mathrm{~kg} / \mathrm{m}^{2}$ had been consumed, leaving sufficient time between each coat for drying, within which period surface damping took place on two occasion, so as to facilitate the penetration of the inhibitor. The specimens were introduced once again into a damp chamber, gradually damping their surface and successively measuring their corrosion potential and corrosion rate.
Finally, rebar loss of mass was then quantified by means of gravimetry, in both the LFS and the reference specimens. The loss of mass in the rebars was determined in the following phases:

The specimens were broken up and the steel rebars separated from the mortar by mechanical means. The rebars were then brushed and introduced into $\mathrm{HCl}$ at $50 \%$, mixed with $4 \mathrm{~g} / 1$ of hexamethylenetetramine (urotropine) for $24 \mathrm{~h}$ for descaling. They were then cleaned and dried.

The rebars were then cut, separating their working lengths from the rest of the rebar. The cut rebars were numbered and weighed and the loss of mass in the rebars was calculated.

\subsection{Measurement techniques}

Since its demonstration that the polarization curves could be likened to straight lines in environments with reduced corrosion potentials, a relation was established between the slopes of those straight lines and the corrosion rate:

$R_{\mathrm{p}}=\Delta E / \Delta i=B / I_{\text {corr }}$

$B=b_{\mathrm{a}} \cdot b_{\mathrm{c}} / 2.3 \cdot\left(b_{\mathrm{a}}+b_{\mathrm{c}}\right)$

where $I_{\text {corr }}$ is the corrosion intensity, $B$ is a constant that depends on the slopes of Tafel, $b_{\mathrm{a}}$ and $b_{\mathrm{c}}, \Delta i$ is the response in current over surface area to a small stepping up of the power $\Delta E$ applied to the system and vice versa and $R_{\mathrm{p}}$ the polarization resistance $[37,38]$.

Given that

$I_{\text {corr }}=i_{\text {corr }} / S$,

another way of expressing the earlier relation is:

$i_{\text {corr }}=B \cdot S / R_{\mathrm{p}}$

where $i_{\text {corr }}$ is the corrosion rate, $B$ is the Stern and Geary constant, $S$ the electrode surface and $R_{\mathrm{p}}$ is the polarization resistance.

The constant $B$ is in the majority between 13 and $52 \mathrm{mV}$, such that when $26 \mathrm{mV}$ is employed as the value for $B$, the maximum error factor is 2 [39|.

Table 4

Mortar composition.

\begin{tabular}{|c|c|c|c|c|}
\hline Label & Description & $\mathrm{w} / \mathrm{c}$ & $\%$ Chloride ion & $\mathrm{ClCa}_{2}(\mathrm{~g})$ \\
\hline MAC-0,0 & 1: 6: w (cement/sand/water) & 1.02 & 0.0 & 0.00 \\
\hline MAC-0.4 & $1: 6: \mathrm{w}$ & 1.02 & 0.4 & 0.80 \\
\hline MAC-0.8 & $1: 6: w$ & 1.02 & 0.8 & 1.60 \\
\hline $\mathrm{MAC}-1.2$ & $1: 6: w$ & 1.02 & 1.2 & 2.40 \\
\hline MAC-2.0 & $1: 6: w$ & 1.02 & 2.0 & 4.00 \\
\hline MAE-0.0 & Substitution of cement ( $30 \%$ ) and sand ( $25 \%$ ) by LFS & 1.68 & 0.0 & 0.00 \\
\hline MAE-0.4 & Substitution of cement ( $30 \%$ ) and sand ( $25 \%$ ) by LFS & 1.68 & 0.4 & 0.55 \\
\hline MAE-0.8 & Substitution of cement ( $30 \%$ ) and sand ( $25 \%$ ) by LFS & 1.68 & 0.8 & 1.10 \\
\hline MAE-1.2 & Substitution of cement ( $30 \%$ ) and sand $(25 \%)$ by LFS & 1.68 & 1.2 & 1.65 \\
\hline MAE-2.0 & Substitution of cement ( $30 \%$ ) and sand (25\%) by LFS & 1.68 & 2.0 & 2.75 \\
\hline
\end{tabular}
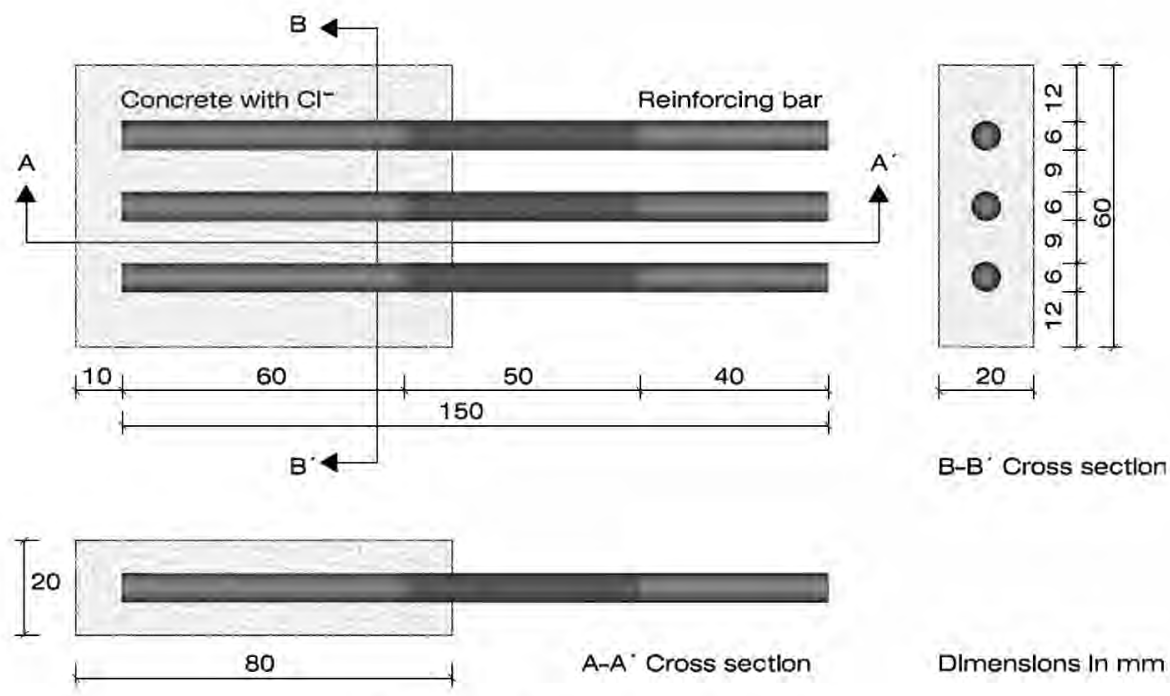

Fig. 1. LFS and reference mortar specimens. 

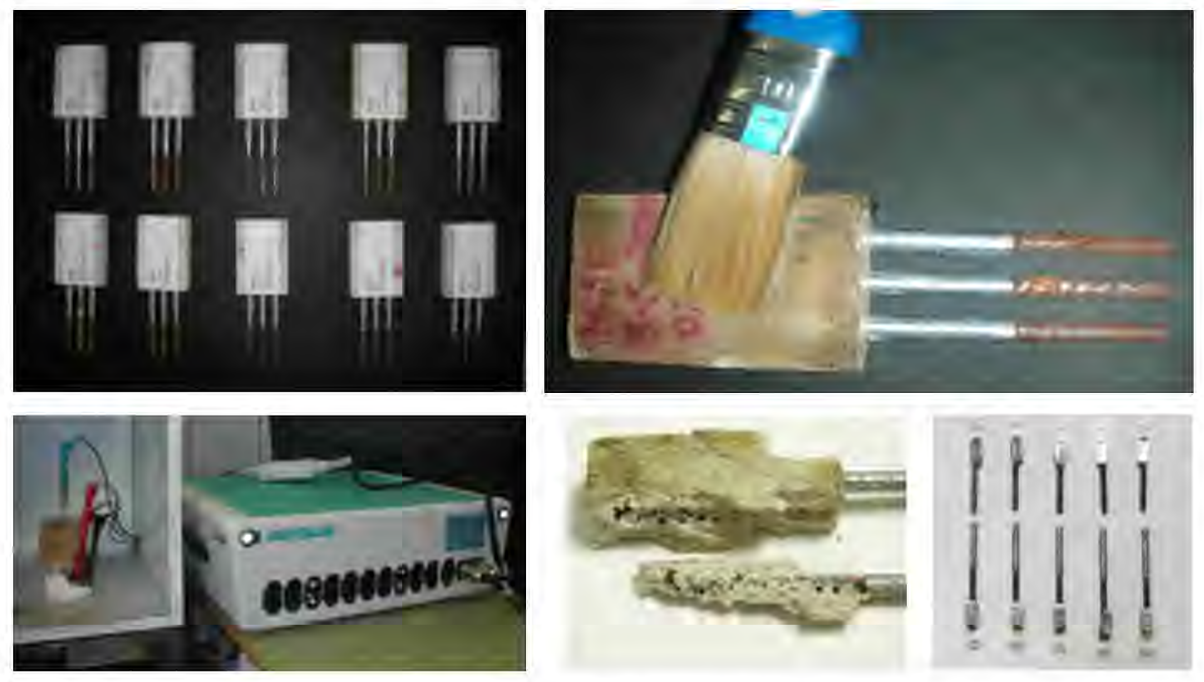

Fig. 2. Test set-up for the experiment.

The comparison between corrosion behavior through the measurement of corrosion potentials, according to standard ASTM 876-09 [40 4 and through the calculation of corrosion rates, confirms that corrosion potentials offer us qualitative information on the corrosion process, although quantitative techniques such as corrosion rates have to be applied, in order to understand the corrosion process and its evolution [41]. There are many studies that have measured corrosion potentials and corrosion rates and have concluded that corrosion rate measurements are more reliable than corrosion potential measurements, following investigations into the behavior of steel bars embedded in concrete [42] and in an evaluation of the useful life of reinforced concrete structures [43]. The value obtained from the corrosion potential or open-circuit potential $\left(E_{\text {corr }}\right)$, with regard to the reference electrode is used to establish a corrosion-related risk [40] while the corrosion rate $\left(i_{\text {corr }}\right)$ quantifies corrosion behavior [44-46]. The reference values for both measurements may be found in Table 5 .

A potentiostat (AUTOLAB/PGSTAT302N) was used for electrochemical measurements, in which the central rebar of each specimen was used as the working electrode and an adjacent steel rebar as the counter-electrode. A damp cloth was placed between the reference electrode, a silver silver-chloride (SSCE; +0.222 V SHE) electrode, and the specimen to ensure a secure contact.

\section{Results and analysis}

Figs. $3 \mathrm{a}$ and $3 \mathrm{~b}$ show the corrosion potential results both in the LFS specimens and in the reference specimens, for the five chloride ion percentages by weight of cement. The graphs show that, in both cases, the corrosion potentials increased with the passage of time (and therefore with the moisture content of the specimens) and with the ion chloride percentage of the specimens by weight of cement. As a consequence of the natural drying of the specimens, which was necessary before surface application of the corrosion inhibitor, the corrosion potential fell abruptly until positive values were reached, regardless of the chloride ion percentage of each specimen, which demonstrates the sensitivity of corrosion potential measurements to humidity.

Table 5

Cotrosion-related tisks.

\begin{tabular}{lll}
\hline Measurement & Risk & Values \\
\hline$E_{\text {corr }}(\mathrm{mV})$ & High $>90 \%$ & $E_{\text {corr }}<-231$ \\
& Uncertainty & $-231<E_{\text {corr }}<-81$ \\
& Low $<10 \%$ & $E_{\text {corr }}>-81$ \\
$i_{\text {corr }}\left(\mu \mathrm{A} / \mathrm{cm}^{2}\right)$ & Active state & $i_{\text {corr }}>1 \mu \mathrm{A} / \mathrm{cm}^{2}$ \\
& High corrosion & $0.5 \mu \mathrm{A} / \mathrm{cm}^{2}<i_{\text {corr }}<1 \mu \mathrm{A} / \mathrm{cm}^{2}$ \\
& Low corrosion & $0.1 \mu \mathrm{A} / \mathrm{cm}^{2}<i_{\text {corr }}<0.5 \mu \mathrm{A} / \mathrm{cm}^{2}$ \\
& Passive state & $i_{\text {corr }}<0.1 \mu \mathrm{A} / \mathrm{cm}^{2}$ \\
\hline
\end{tabular}

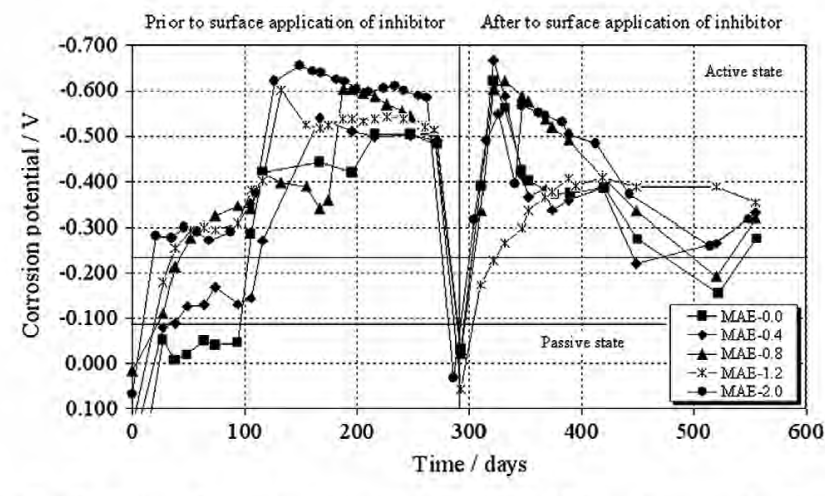

Fig. 3a. Evolution of corrosion potential over time, in LFS specimens, with different percentages of chloride ions and following surface-application of the corrosion inhibitor.

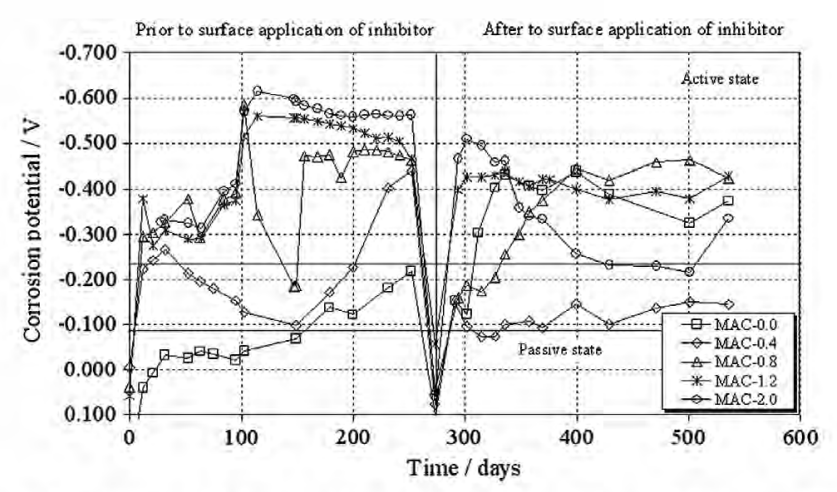

Fig. 3b. Evolution of corrosion potential over time, in the reference specimens, with different chloride-ion percentages, before and after surface application of the corrosion inhibitor.

Once the corrosion inhibitor had been applied to the surface and the specimens returned to the damp chamber, a rapid increase occurred in the corrosion potentials, which then remained steady or fell over time, although they remained within active state values.

The results of the corrosion rate for the LFS and the reference specimens in the first phase of the experiment are shown below 
in Table 6. As may be observed, the reference specimens with chloride ion percentages below or equal to $0.4 \%$ by weight of cement remained in a passive state, while the LFS specimens started to show signs of corrosion after 160 days of exposure. The rebars reached high and very high corrosion rate values over similar periods of time, in both the LFS specimens and the reference specimens with chloride ion percentages of over $0.4 \%$.

In Figs. $4 a-4 e$ the behavior of the LFS specimens and the reference specimens may be compared during the experimental process, through the corrosion rate measurements for the chloride ion percentages of $0.0 \%, 0.4 \%, 0.8 \%, 1.2 \%$ and $2.0 \%$. The results obtained show that the corrosion rates of all of the specimens increased over time, with the chloride ion percentages, until the specimens were dry for surface application of the inhibitor. At that point, the corrosion rate decreased to passive state values, only to increase once again when the inhibitor had been applied and the specimens had been dampened. A similar behavior was also observed in the two samples prepared for each type of specimen.

As may be seen in Fig. 4a, before application of the inhibitor, the corrosion rate is greater in LFS specimens than in the reference specimens. Having applied the inhibitor, the corrosion rates of both types equal out; the corrosion rates are maintained in the LFS specimens and increase in the reference specimens, but are held in both cases within passive state values.

In the specimens with $0.4 \%$ chloride ions (Fig. $4 \mathrm{~b}$ ), the measurements were maintained at similar values before and after application of the inhibitor, with passive-state values in the reference specimens. In the specimens with $0.8 \%$ chloride ions (Fig. 4c) and with LFS, the corrosion rates descended slightly, though they stayed at high corrosion values, while the corrosion rates in the reference specimens slowed to low corrosion rates. The behavior of both the LFS specimens and the reference specimens with chloride ion percentages of $1.2 \%$ and $2.0 \%$ was similar, staying at corrosion rates in the active state after surface application of the inhibitor (Figs. $4 \mathrm{~d}$ and $4 \mathrm{e}$ ).

Fig. 5 shows the symptomology of corrosion in rebars with $0.4 \%$ chloride ions ( $a$ and $c$ ) and with $2 \%$ chloride ions (b and d).

The symptoms caused by corrosion of the steel rebars were not evident on the exterior of the reference specimens, or on the exterior of the LFS specimens, but they were in the rebars themselves, as may be seen in Fig. 5, in which oxide stains and losses of section may be seen.

In the rebars with $0.4 \%$, the mass loss is less evident than in the specimens with $2 \%$ chloride ions, and it is more evident in the LFS specimens than in the reference specimens, symptoms that are coherent with the results obtained with electrochemical and gravimetric techniques.

\section{Discussion}

Figs. 3a and 3b show more negative corrosion potentials in the LFS specimens than in the reference specimens, in the first phase of

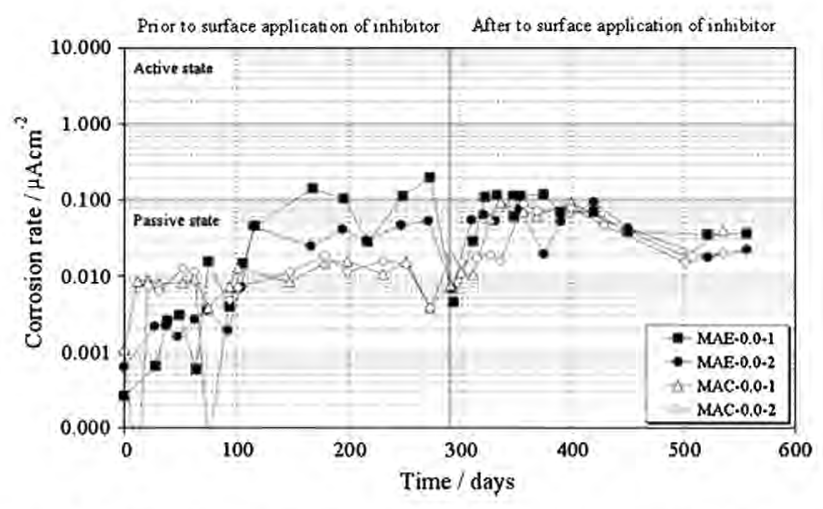

Fig. 4a. Evolution of $i_{\text {corr }}$ over time in both the LFS specimens and the reference specimens without chloride ions.

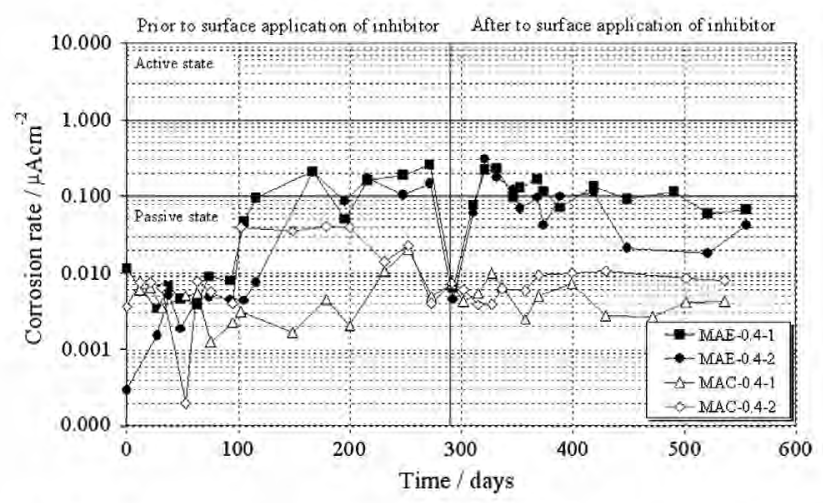

Fig. $\mathbf{4 b}$. Evolution of $i_{\text {corr }}$ over time in both the LFS specimens and the reference specimens with $0.4 \%$ chloride ions by weight of cement.

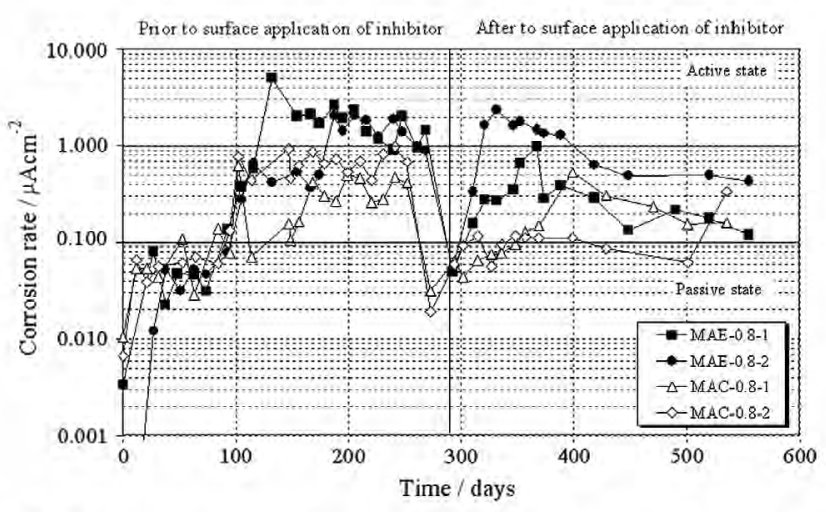

Fig. 4c. Evolution of $i_{\text {cotr }}$ over time in both the LFS specimens and the reference specimens with $0.8 \%$ chloride ions by weight of cement.

Table 6

Corrosion process in the first phase of the experiment, in the LFS specimens and in the reference specimens.

\begin{tabular}{|c|c|c|c|c|c|c|c|}
\hline & \multirow[t]{2}{*}{ Corrosion rate } & \multirow[t]{2}{*}{ State } & \multicolumn{5}{|c|}{ Corrosion states in the first phase, in days } \\
\hline & & & $0.0 \%$ & $0.4 \%$ & $0.8 \%$ & $1.2 \%$ & $2.0 \%$ \\
\hline MAE & $\begin{array}{l}0.1 \mu \mathrm{A} / \mathrm{cm}^{2}<i_{\text {corr }}<0.5 \mu \mathrm{A} / \mathrm{cm}^{2} \\
0.5 \mu \mathrm{A} / \mathrm{cm}^{2}<i_{\text {corr }}<1 \mu \mathrm{A} / \mathrm{cm}^{2} \\
i_{\text {corr }}>1 \mu \mathrm{A} / \mathrm{cm}^{2}\end{array}$ & $\begin{array}{l}\text { Low corrosion } \\
\text { High corrosion } \\
\text { Active state }\end{array}$ & $\begin{array}{l}168 \\
- \\
-\end{array}$ & $\begin{array}{l}160 \\
- \\
-\end{array}$ & $\begin{array}{l}93 \\
116 \\
120\end{array}$ & $\begin{array}{l}51 \\
110 \\
116\end{array}$ & $\begin{array}{l}49 \\
74 \\
115\end{array}$ \\
\hline MAC & $\begin{array}{l}0.1 \mu \mathrm{A} / \mathrm{cm}^{2}<i_{\text {corr }}<0.5 \mu \mathrm{A} / \mathrm{cm}^{2} \\
0.5 \mu \mathrm{A} / \mathrm{cm}^{2}<i_{\text {corr }}<1 \mu \mathrm{A} / \mathrm{cm}^{2} \\
i_{\text {corr }}>1 \mu \mathrm{A} / \mathrm{cm}^{2}\end{array}$ & $\begin{array}{l}\text { Low corrosion } \\
\text { High corrosion } \\
\text { Active state }\end{array}$ & $\begin{array}{l}- \\
- \\
-\end{array}$ & $\begin{array}{l}- \\
- \\
-\end{array}$ & $\begin{array}{l}84 \\
168 \\
-\end{array}$ & $\begin{array}{l}65 \\
96 \\
102\end{array}$ & $\begin{array}{l}40 \\
84 \\
90\end{array}$ \\
\hline
\end{tabular}




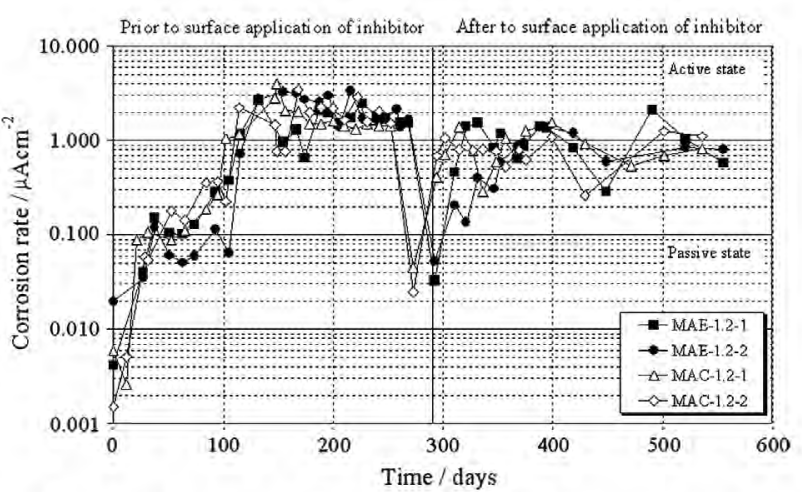

Fig. 4d. Evolution of $i_{\text {corr }}$ over time in both the LFS specimens and the reference specimens with $1.2 \%$ of chloride ions by weight of cement.

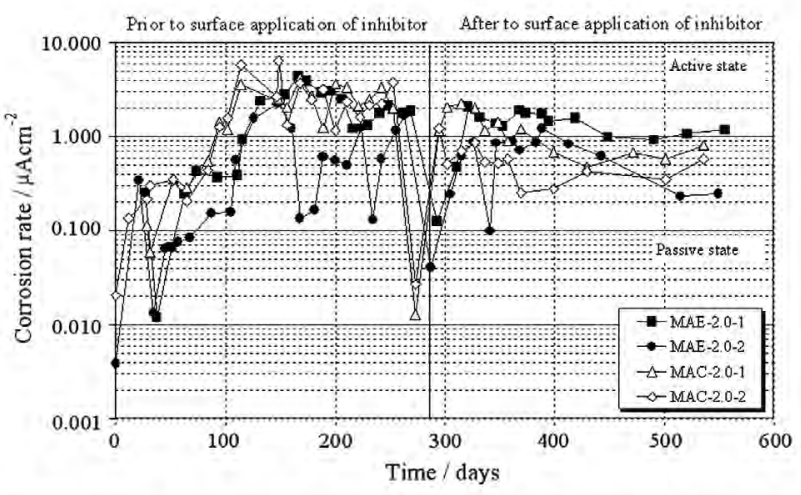

Fig. 4e. Evolution of $i_{\text {corr }}$ over time in both the LFS specimens and the reference specimens with $2.0 \%$ ion chloride by weight of cement.

the experiment. Once the corrosion inhibitor had been applied, the corrosion potentials fell in the LFS specimens and stayed at similar levels in the reference specimens, although they both maintained active state values.

It may be seen in Fig. $4 \mathrm{~b}$ that in the specimens with $0.4 \%$ chloride ions, the corrosion rate is higher in LFS specimens than in the reference specimens, maintaining stable values before and after the application of surface corrosion inhibitor and in both cases at passive state values. In the reference specimens with chloride ion

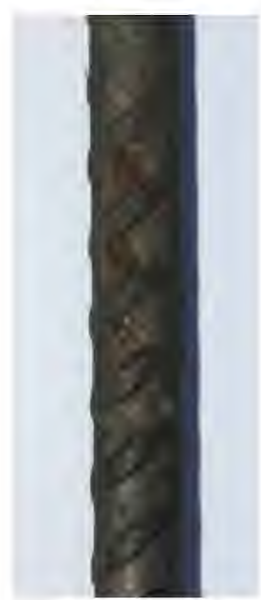

(a)

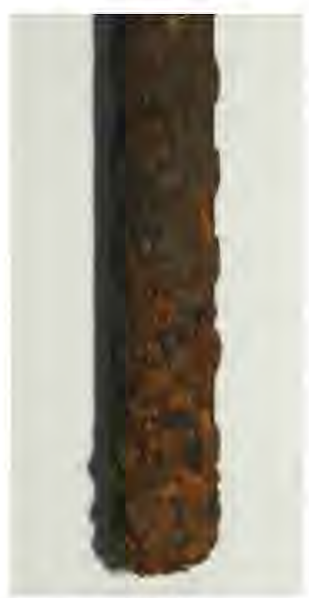

(b)

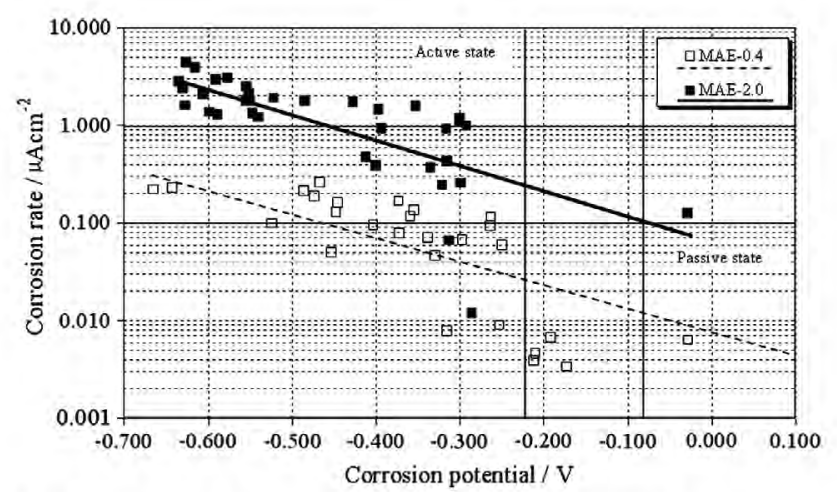

Fig. 6a. Comparison of corrosion rate and corrosion potential in LFS specimens, with $0.4 \%$ and $2 \%$ of chloride ions by weight of cement.

percentages of $0.8 \%$ ( $\mathrm{Fig}, 4 \mathrm{c}$ ), the corrosion rate falls to low corrosion values, while in the reference specimens with chloride ion percentages of $1.2 \%$ and $2 \%$ (Figs. $4 \mathrm{~d}$ and $4 \mathrm{e}$ ), the corrosion rates are not reduced following application of the surface corrosion inhibitor (these results being coherent with other studies such as those by Söylev et al. [32] and Bolzoni et al. [47]. In LFS specimens and with chloride ion percentages of over $0.4 \%$, the corrosion rates do not fall, and the application of the inhibitor is in no case effective (Figs, $4 \mathrm{~b}-4 \mathrm{e}$ ).

Subsequently, the coherence of the results for corrosion potential and corrosion rate measurement were tested in Figs. 6a and 6b, corresponding to the LFS specimens and the reference specimens, respectively. A rising trend line may be observed in both the LFS specimens and in the reference specimens and, in consequence, as the corrosion potential rose, so too did the corrosion rate, reaching higher values for both measurements where chloride ion percentages were $2.0 \%$. The coherence of the results was more conclusive with chloride ion percentages of $2 \%$, as more negative corrosion potentials of $-231 \mathrm{mV}$ occurred in the specimens with $0.4 \%$ chloride ions, which suggests a $90 \%$ probability that the rebar was in an active state, and that its corrosion rates corresponded to the passive state or to low-level corrosion. Comparing the trend lines, the similarity to chloride-ion percentages of $2.0 \%$ may be observed, which implies a similar behavior in the LFS specimens and in the reference specimens. The disparity in the trend lines shows the progress of the corrosion process in LFS specimens in comparison with the reference specimens.

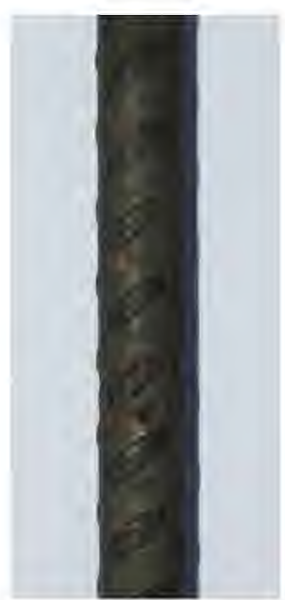

(c)

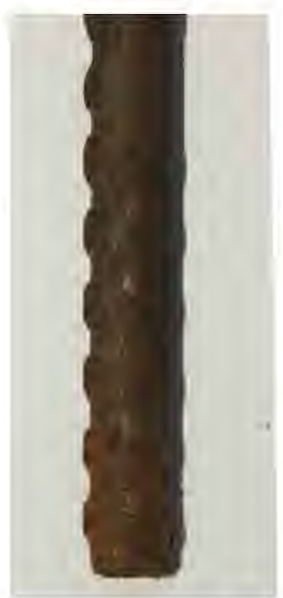

(d)

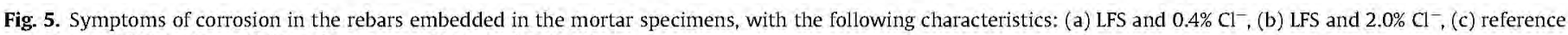
specimen with $0.4 \% \mathrm{Cl}^{-}$and (d) reference specimen with $2.0 \% \mathrm{Cl}^{-}$. 


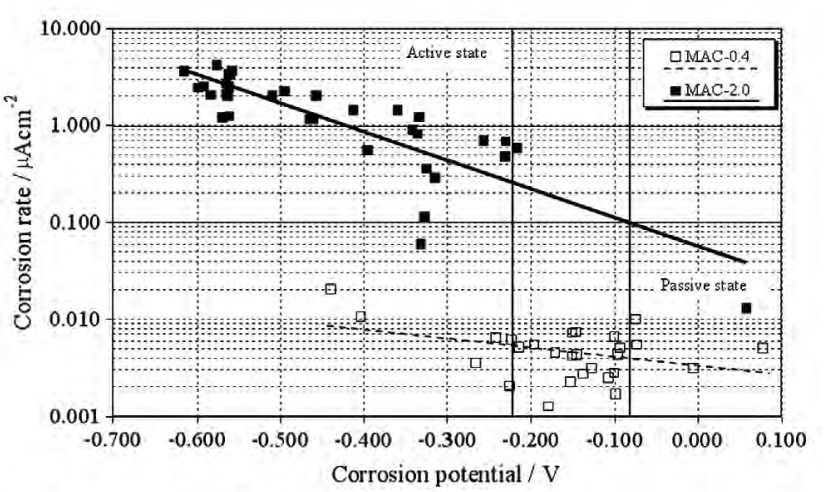

Fig. 6b. Comparison of corrosion rate and corrosion potential in reference specimens, with $0.4 \%$ and $2 \%$ chloride ions by weight of cement.

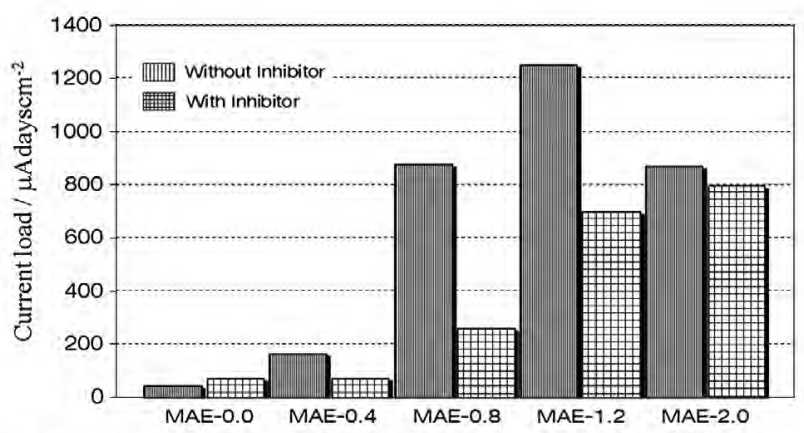

Fig. 7a. Comparison of current load in LFS specimens, with and without inhibitor.

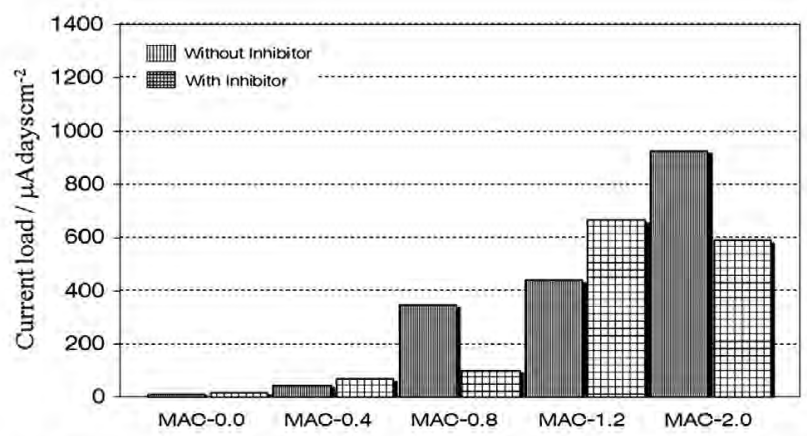

Fig. 7b. Comparison of current load in reference specimens, with and without inhibitor.

Figs. 7a and 7b show that the current load was lower in specimens with chloride ion percentages equal to or below $0.4 \%$ than in specimens with chloride ion percentages above the limit established by the EHE, with no differences between the LFS specimens and the reference specimens. It may also be seen that the current load was lower in specimens to which the inhibitor had been applied.

Comparing graphs $7 \mathrm{a}$ and $7 \mathrm{~b}$, it may be seen that the current load was lower in the reference specimens than in the LFS specimens, both before and after application of the inhibitor.

\section{Conclusions}

- In both the LFS specimens and the reference specimens, the corrosion potential and the corrosion rate increased with the moisture content of the specimens and the chloride ion percentages by weight of cement introduced at the mixing stage.
- The behavior with regard to corrosion in mortars with no chlorides or with percentages of $0.4 \%$ by weight of cement, an established threshold in numerous standards, was better in the reference specimens than in the mortars with part of the cement and aggregate content replaced with LFS, although the results were not sufficiently conclusive to determine a different behavior between both types of mortar, as the corrosion rates that were measured in all cases corresponded to the passive state.

- In mortars with chloride ion percentages of $0.8 \%, 1.2 \%$ and $2.0 \%$ by weight of cement, the rebars were in an active state, behaving in a similar way under corrosion in both the reference specimens and the LFS specimens.

- The loss of mass due to corrosion was greater in the LFS specimens than in the reference specimens and increased with the percentage of chloride ions in the specimens.

- In LFS specimens, the surface-applied corrosion inhibitor was not effective at any chloride ion percentage over $0.4 \%$.

- The corrosion inhibitor was capable of lowering the corrosion rate to low corrosion values in both the reference mortars and the mortars with chloride ion percentages of $0.08 \%$, but it was not capable of changing the rebars once again to the passive state in specimens with chloride ion percentages of $1.2 \%$ and $2 \%$.

- As a final conclusion, it may be pointed out that, in states of advanced corrosion, the surface inhibitor was neither efficient in the LFS specimens nor in the reference specimens.

\section{References}

[1] RILEM. Corrosion of steel in concrete. Report of the Technical Committee 60CSC; 1989.

[2] EHE. Instrucción de Hormigón Estructural. Ministerio de Fomento. Madrid, Spain; 2008, pp. 110-16.

[3] Eurocode 2-EN 1992. Design of concrete structures, Part 1.1: general rules and rules for buildings; 4 . European committee for standardization, brussels; 2004 , pp. $72-82$.

[4] ACI-318S-08. Building code requirements for structural concrete (ACI-318-08) and commentary. American Concrete Institute, Farmington Hills, Ml; 2008, pp. $59-66$.

[5] CEB-FIB Model Code 1990. Comité Euro-International du Béton, Lausanne, Switzerland; 1993, pp. 264-85.

[6] Shi X, Xie N, Fortune K, Gong J. Durability of steel reinforced concrete in chloride environments: an overview. Construct Build Mater 2012;30:125-38.

[7] Ožbolt I, Balabanič G, Periškič G, Kušter M. Modelling the effect of damage on transport processes in concrete. Construct Build Mater 2010;24(9):1638-48.

[8] Malheiro $R$, Meira $G$, Lima $M$, Perazzo N. Influence of mortar rendering on chloride penetration into concrete structures. Cem concr Compos 2011;33:233-9.

[9] Loreto G, Varriale C, Iovino R. Experimental evaluation of concrete durability. XXXVII IAHS, World Congress on Housing, Spain; 2010.

[10] Chang ZT, Cherry B, Marosszeky M. Polarisation behavior of steel bar samples in concrete in seawater. Part 1: experimental measurement of polarisation curves of steel in concrete. Corros Sci 2008;2(50):357-64.

[11] Moth H, Geiseler J. Products of steel slags an opportunity to save natural resources. Waste Manage 2001:21(3):285-93.

[12] Mehta PK. Bringing the concrete industry into a new era of sustainable development. In: Mehta PK, editor, Proc Mario Collepardi symp on 'advances in concrete science and technology', Rome, Italy; 1997, pp. 49-67.

[13] Berndt ML. Properties of sustainable concrete containing fly ash, slag and recycled concrete aggregate. Construct Build Mater 2009;23:2606-13.

[14] Tlker Bekir Topçu, Ahmet Raif Boğa. Effect of boron waste on the properties of mortar and concrete. Waste Manage Res 2010;28:626-33.

[15] Pasetto M, Baldo N. Experimental evaluation of high performance base course and road base asphalt concrete with electric arc furnace steel slags. J Hazard Mater 2010;181(1-3):938-48.

[16] Srinivasa A, Pradhan PK, Chandra S. Utilization of Basic Oxygen Furnace (BOF) slag in the production of a hydraulic cement binder. Int J Mineral Process 2006; 79(2):98-105.

[17] Das B, Prakash S, Reddy PSR, Misra VN. An overview of utilization of slag and sludge from steel industries. Resour, Conservation Recycling $2007 \div 50(1): 40-57$.

[18] Tufekci M, Demirbas A, Genc H. Evaluation of steel furnace slags as cement additives. Cem Concr Res 1997;27(11);1713-7.

[19] Setién J, Hernández D, González IJ. Characterization of ladle furnace basic slag for use as a construction material. Construct Build Mater 2009;23:1788-94. 
[20] Manso JM, Rodríguez A, Aragón A, González JJ. The durability of masonry mortars made with ladle furnace slag. Construct Build Mater $2011 ; 25(8): 3508-19$.

[21] Rodríguez A, Manso JM, Aragôn A, Gonzâlez JJ. Strength and workability of masonry mortars manufactured with ladle furnace slag. Resour, Conservation Recycling 2009;53:645-51.

[22] Rodríguez A. Fabricación de morteros de albañilería con escoria blanca de horno cuchara y su utilización en construcción. Doctoral Thesis. Universidad de Burgos, Spain; 2008.

[23] Prieto M, Cobo A, Rodríguez A, Calderón V. Corrosion behavior of reinforcement bars embedded in mortar specimens containing ladle furnace slag in partial substitution of aggregate and cement. Construct Build Mater 2013;38:188-94.

[24] Prieto I. Análisis del comportamiento a corrosión de armaduras embebidas en probetas de mortero, con sustitución parcial de áridos y cemento por escorias blancas de horno cuchara. Doctoral Thesis. Universidad Politécnica de Madrid Spain; 2012.;

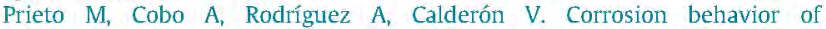
reinforcement bars embedded in mortar specimens containing ladle furnace slag in partial substitution of aggregate and cement. Construct Build Mater 2013;38:188-94.

[25] Söylev TA, Richardson MG. Corrosion inhibitors for steel in concrete: state-ofthe-art report. Construct Build Mater 2008;22(4):609-22.

[26] Saraswathy V, Muralidharan S, Kalyanasundaram RM, Thangavel K, Srinivasan $S$. Evaluation of a composite corrosion-inhibiting admixture and its performance in concrete under macrocell corrosion condition. Cem Concr Res 2001;31(5):789-94

[27] Zheng H, Li W, Mab F, Kong Q. The effect of a surface-applied corrosion inhibitor on the durability of concrete. Construct Build Mater 2012:37:36-40.

[28] Schutter G, Luo L. Effect of corrosion inhibiting admixtures on concrete properties. Construct Build Mater 2004;18:483-9.

[29] Jamil HE, Montemor MF, Boulif R, Shriri A, Ferreira MGS. An electrochemica and analytical approach to the inhibition mechanism of an amino-alcohol based corrosion inhibitor for reinforced concrete. Electrochim Acta $2003 ; 48: 3509-18$.

[30] Ormellese M, Berra M, Bolzoni F, Pastore T. Corrosion inhibitors for chlorides induced corrosion in reinforced concrete structures. Cem Concr Res $2006 ; 36: 536-47$.
[31] Reoua JS, Annb KY. The electrochemical assessment of corrosion inhibition effect of calcium nitrite in blended concretes. Mater Chem Phys $2008 ; 109: 526-33$.

[32] Söylev TA, McNally C, Richardson M. Effectiveness of amino alcohol-based surface-applied corrosion inhibitors in chloride-contaminated concrete. Cem Concr Res 2007;37:972-7.

[33] Criado M, Monticelli C, Fajardo S, Gelli D, Grassi V, Bastidas JM. Organic corrosion inhibitor mixtures for reinforcing steel embedded in carbonated alkali-activated fly ash mortar. Construct Build Mater 2012;35:30-7.

[34] Tritthart J. Transport of a surface-applied corrosion inhibitor in cement paste and concrete. Cem and Concr Res 2003;33(6):829-34.

[35] RC-08. Instrucción para la recepción de cementos; 2008, pp. 45-52.

[36] UNE-EN 13139. AENOR; 2003.

[37] Stern M, Geary AL. Electrochemical polarization: I. A theorical analysis of the shape of the polarization curves. J Electrochem Soc 1957;104(1):56-63.

[38] Stern M, Weisert ED. Experimental observations on the relation between polarization resistance and corrosion rate. Proc Am Soc Test Mater $1959 ; 59: 1280$

[39] Song G. Theoretical analysis of the measurement of polarisation resistance in reinforced concrete. Cem Concr Compos 2000;22(6):407-15.

[40] ASTM C876-09. Standard Test Method for Half-cell Potentials of uncoated reinforcing steel in concrete.

[41] González JA, Miranda JM, Feliú S. Considerations on reproducibility of potential and corrosion rate measurements in reinforced concrete. Corros Sci $2004 ; 46(10): 2467-85$.

[42] Huang R, Chang Jl. WU JK. Correlation between corrosion potential and polarization resistance of rebar in concrete. Mater Lett 1996;28(4-6):445-50.

[43] Khatri RP, Sirivivatnanon V, Heeley AP. Critical polarization resistance in service life determination. Cem Concr Res 2004;34(5):829-37.

[44] Network D. Manual de inspección, evaluaciôn y diagnôstico de corrosión en estructuras de hormigón armado. Río de Janeiro: CYTED programe; 1997.

[45] Broomfield JP. Life prediction of corrodible structures. NACE Symposium, Cambridge; Sept. 1991, Paper 14.

[46] González JA, Miranda J. Corrosión en las estructuras de hormigón armado: Fundamento, medida, diagnosis y prevención. 2007, CSIC, Madrid, Spain.

[47] Bolzoni F, Goidanich S, Lazzari L, Ormellese M. Corrosion inhibitors in reinforced concrete structures Part 2 - repair system. Corros Eng Sci Technol $2006: 41(3): 212-20$. 